\title{
Mateusz Hübner
}

(Nicolaus Copernicus University in Toruń; Institute for the History of Science of the Polish Academy of Sciences, Poland)

https://orcid.org/0000-0003-0438-4315

E-mail: mateuszhubner@wp.pl

\section{The Role of the Polish Academy of Arts and Sciences in Building the Prestige of the Reborn Second Republic of Poland}

\section{Rola Polskiej Akademii Umiejętności w budowaniu prestiżu odrodzonej II Rzeczypospolitej}

\section{ABSTRACT}

The article shows the importance of the Polish Academy of Arts and Sciences (PAU) in building the prestige of the Polish state, reborn in 1918. It investigates primarily the first years of independence in which the Academy undertook actions aimed at gaining Polish science an international reputation. The scope and nature of the PAU's cooperation with the authorities of the Republic of Poland - in particular with the Ministry of Foreign Affairs - was analyzed. The article is based on source materials - both archival and published - and literature on the subject. The information contained in the sources and published works has been critically evaluated, taking into account the specificity of the analyzed material. Based on the statutory objectives of the PAU, various forms of the Academy's work

\begin{tabular}{|l|l|l|l|}
\hline \multicolumn{2}{|l|}{ PUBLICATION INFO } \\
\hline
\end{tabular}


were presented, which were related to building the importance of Polish science abroad. Reference was made to the involvement of the PAU in the work of international scientific organizations - the Conseil International de Recherches and the Union Académique Internationale de Recherches et de Publications. The influence of Polish national culture (supported and developed by the PAU) on the prestige of the Second Republic of Poland in the international arena indicated that the PAU's actions were necessary in view of the desire to strengthen the position of the Republic of Poland in the circle of scholars from other countries - after years of Polish scientific and cultural achievements being underestimated, marginalized and attributed to others. The importance of support for PAU's activities by the Ministry of Foreign Affairs was established, as well as the beneficial effects but also the dangers related to the entry of politics into the field of science.

Key words: Polish Academy of Arts and Sciences, science, national culture, Second Republic of Poland, Ministry of Foreign Affairs, prestige

National academies as institutions that bring together outstanding people from the world of culture - scholars, writers and artists - are of particular importance ${ }^{1}$. This is due to the role of culture in the broad sense. In internationally established countries, culture fosters internal consolidation and influence on neighboring countries, which is a peaceful form of gaining influence. In Central and Eastern Europe before World War I, domestic science, art and literature made it possible for individual nationalities without statehood to survive. After 1918, national cultures in their own countries were supposed to help consolidate the regained independence. This required international efforts. It was understood that the effectiveness of diplomacy is facilitated by the prestige it possesses in the international community - co-created by achievements in the field of culture. The influence of the outstanding pianist and composer Ignacy Jan Paderewski on the support of the President of the United States, Thomas Woodrow Wilson, for the Polish cause at the end of the war was a significant testimony to this. After the end of the global armed conflict, the authorities of the countries were interested in supporting institutional activities to build their prestige in the international environment. The way to ensure prestige was provided by the initiatives of national academies, as exemplified by the activities of scientists from the Polish Academy of Arts and Sciences [hereinafter: PAU].

The name of the PAU was officially introduced in the statute of 1919. The modification was made possible by the rebirth of the Republic. Earlier, since its transformation from the Krakow Scientific Society in 1872, the

1 Cf. more P. Hübner, Od Towarzystwa Naukowego Krakowskiego do Polskiej Akademii Umiejętności, in: Studia i materiały do dziejów Polskiej Akademii Umiejętności, vol. 1, Kraków 2002, pp. 81-82. 
institution functioned as the Academy of Learning. The Krakow-based PAU, taking on a nationwide character, continued the traditions from before the World War I, when it formally - out of necessity - limited its activities to the Austrian partition. At the dawn of the Independent Republic of Poland, the PAU was an authority in society as a consequence of the well-established tradition of maintaining and developing the Polish national culture devoid of its own state body. The PAU authorities headed by President Kazimierz Morawski - had reasonable hopes that the role of the institution would be appreciated by the Polish authorities, as the development of national culture was in the interest of the reborn state. This development was hindered by limited finances - both of the Academy and the Polish state. According to Jerzy and Henryka Róziewicz: 'The historical upheaval, as a result of which the Polish state was created again, did not put an end to the current crisis in the international position of Polish science. On the contrary, the prolonged duration of the warfare, the destruction and disintegration of the country, and finally the devaluation of Polish money have created new obstacles in establishing scientific relations with other nations' ${ }^{\prime 2}$. The Academy authorities had to adapt their own actions to these difficult realities. The new statute of the Academy, which was drawn up in connection with the restoration of independence, was in practice an amendment to the previous one, which had been approved by Emperor Franz Joseph I on 16 February $1872^{3}$. Nevertheless, the adopted principles were a starting point for the PAU to build the prestige of the independent Republic - not only in Poland, but also internationally.

The fourth paragraph of the 1919 statute states: 'For the development of its tasks, the Academy may establish scientific stations in other towns and countries. As far as the scientific station outside the country is concerned, the approval of the Chief of the Polish State is needed ${ }^{4}$. At the 1st Congress

2 'Przewrót dziejowy, w wyniku którego państwo polskie znowu powstało, wcale nie położył kresu dotychczasowemu kryzysowi w międzynarodowym położeniu nauki polskiej. Przeciwnie, dłuższe znacznie niż gdzie indziej trwanie działań wojennych, wyniszczenie i rozbicie kraju, a wreszcie dewaluacja pieniądza polskiego stworzyły nowe przeszkody w nawiązaniu stosunków naukowych z innymi narodami'. J. Róziewicz, H. Róziewicz, Z dziejów międzynarodowych kontaktów naukowych Polski w latach 1919-1939, 'Problemy Polonii Zagranicznej' 1975, 9, p. 375.

3 Statut Akademii Umiejętności w Krakowie, Kraków 1872. See also: J. Majer, Wstẹp. Sprawa przeobrażenia Towarzystwa Naukowego krakowskiego na Akademije Umiejętności, in: Pamiętnik piętnastoletniej działalności Akademii Umiejętności w Krakowie 1873-1888, Kraków 1889, p. XI; H. Lichocka, Akademia Umiejętności (1872-1918) i jej czescy członkowie, 'Prace Komisji Historii Nauki PAU' 2015, 14, p. 42.

4 ‘Dla rozwijania swych zadań Akademja może ustanawiać stacje naukowe w innych miejscowościach i krajach. O ile idzie o stację naukową poza granicami Państwa potrzebne jest zatwierdzenie Naczelnika Państwa Polskiego'. Statut Polskiej Akademji Umiejętności, 
of Polish Science, organized by the Józef Mianowski Fund, which lasted from 7 to 10 April 1920, historian Władysław Konopczyński postulated the creation of Polish scientific stations in 'major centers of European thought'. In Konopczyński's opinion, each such institution should serve as an 'embassy of Polish culture'. The historian referred to the stations' tasks: 'By deepening and promoting knowledge, it should at the same time contribute to the development and presentation of other sections of national culture, i.e. mainly artistic culture, to foreigners. Representatives of our music, literature, theatre and visual arts could gather at the station; its materials could be used in the exhibition of the Press and Propaganda Office. Moreover, the station's scope of tasks would include: 1) strengthening relations with the scientific world of a given country, especially with publishers of books and journals, 2) publishing in journals the works of Polish authors, 3) supervising the work of scholarship holders of various institutions, 4) conducting research, collecting information and materials for scientists and national institutions, 5) running an information office where foreign scientists would seek information from various scientific fields concerning Poland' ${ }^{5}$.

Already in the first period of the Second Republic of Poland there was a PAU Scientific Station in Paris - operating since 1893 as a result of an agreement with the Historical and Literary Society. The difficult financial

Kraków 1920, p. 4. The General Assembly of the PAU - 18 June 1924 - unanimously adopted the new statute. This statute was ratified by the Council of Ministers on 16 March 1927. The new statute included modifications in the fourth paragraph: 'Polska Akademia Umiejętności może ustanawiać swych delegatów, tworzyć zakłady i stacje naukowe, bądź w innych miejscowościach Rzplitej Polskiej, bądź poza jej granicami. Do założenia trwałej stacji naukowej poza granicami państwa potrzebne jest zezwolenie Prezydenta Rzplitej' ['The Polish Academy of Arts and Sciences may appoint its delegates, establish branches and scientific stations, either in other places in the Republic of Poland or abroad. In order to establish a permanent scientific station outside the country, permission of the President of the Republic of Poland is required']. Statut Polskiej Akademji Umiejętności, Kraków 1927, p. 4.

5 'Służąc przedewszystkiem pogłębianiu i krzewieniu wiedzy, powinna ona zarazem, bez ujmy dla czystości swego kierunku naukowego, przyczyniać się do rozwoju, tudzież do pokazania cudzoziemcom innych działów kultury narodowej, a więc głównie - kultury artystycznej; przy stacji mogliby się grupować przedstawiciele naszej muzyki, literatury, teatru, sztuk plastycznych; z jej materjałów korzystaćby mogła ekspozytura Biura Prasowego i Propagandy. Pozatem, we właściwym swoim zakresie powinnaby stacja: 1) zacieśniać stosunki ze światem naukowym danego kraju, zwłaszcza $z$ wydawcami książek i czasopism, 2) umieszczać w czasopismach prace polskich autorów, 3) sprawować dozór nad pracą stypendystów różnych instytucyj, 4) prowadzić poszukiwania, zbierać informacje i materjały dla uczonych i instytucyj krajowych, 5) prowadzićbiuro informacyjne, w którem uczeni obcy zasięgaliby wiadomości z różnych dziedzin naukowych, dotyczących Polski'. W. Konopczyński, Nauka polska na terenie międzynarodowym, 'Nauka Polska' 1920, 3, pp. 201-202. 
situation made it impossible for the Academy to maintain the Station and the associated Polish Library on its $\mathrm{own}^{6}$. At one point, the Academy - on the basis of a resolution of the General Assembly (28 November 1919) - even asked the Council of Ministers in 1920 to take over 'its Polish Scientific Station in Paris ${ }^{\prime 7}$. The PAU only wanted to maintain its influence on the direction of scientific activities undertaken by the Station. The Polish authorities were not interested in this solution, so in the end the Station remained with the PAU. The authorities decided on another form of assistance - the transfer of small subsidies that saved the Station from liquidation. It might seem that the authorities did not appreciate unlike scientists - the importance of the Scientific Station in building the prestige of Poland on the international arena. This significance resulted from the possibility of influencing French intellectual circles through it in the Polish spirit. On the other hand, in the first period after World War I, Polish authorities had other priorities - the main goal was to maintain independence, which made the issue of science secondary and even marginalized. This was reflected in the lack of support for the extensive program of development of the Polish Station in Paris.

The funds that the authorities ultimately passed on to the Station did not enable it to carry out its tasks within the scope presented by Władysław Konopczyński. Nevertheless, Konopczyński believed that it was possible to change this state in the future. He considered the expansion of the operations of the existing institution in Paris and the creation of new stations and scientific expeditions to be necessary due to the building of Poland's prestige in the international arena. In his opinion, 'scientific stations and expeditions of a temporal nature should also, as far as possible, take care to mediate between Polish and local science, and not only conduct research, but also try to propagate our scientific thought ${ }^{\prime}$. This required the support of the central authorities of the Second Republic of Poland, as it could not be ensured by private patronage, whose importance in the post-war reality was limited.

The development of the Scientific Station in Paris depended on the state initiative, to which the Polish scientific community wanted to give

6 The Adam Mickiewicz Museum in Paris is located in the building of the Polish Library. It was founded in 1903 by Władysław Mickiewicz - Adam's son. J. Piskurewicz, Prima inter pares. Polska Akademia Umiejętności w latach II Rzeczypospolitej, Kraków 1998, p. 61.

7 After: D. Rederowa, Formy wspótpracy Polskiej Akademii Umiejętności z zagranica (1873-1952), ‘Studia i Materiały z Dziejów Nauki Polskiej' 1966, 10, p. 125.

8 'stacje i ekspedycje naukowe o charakterze doczesnym powinny również w miare sił dbać o pośrednictwo między nauką polską a miejscowa, i nie tylko prowadzić badania, ale też starać się o propagandę naszej myśli naukowej'. W. Konopczyński, Nauka, p. 202. 
an impulse. Views on scientific stations similar to those of Władysław Konopczyński were presented at the Congress by Stanisław Kutrzeba, a historian of the political system. In his speech entitled 'Science and the State' Kutrzeba, the future Secretary General of the PAU (1926-1939), and then its President (1939-1946), said that one of the tasks of the State would be 'to create Polish scientific stations as a base for exploration or research, or to support and develop those that already exist or existed, such as the Rome Expedition and the Paris station of the Academy of Arts and Sciences; such points of support in England (especially for the natural sciences), in St Petersburg (for historical research), and perhaps even more will have be considered' 9 .

Two months after the end of the Congress - on 20 June 1920 - the PAU Board addressed a memorandum to the Ministry of Religious Denominations and Public Enlightenment, in which it referred to the role of scientific stations, promoting the creation of new ones. The memorandum supported this with the effects of the Paris Station's efforts to maintain relations with scientific circles outside the country. The PAU Station in the French capital was considered to be particularly important for Polish science and culture. This was due to its work in Paris as an important center of inspiration for culture and science in the world. The Academy considered it appropriate to establish several other stations 'taking into account all branches of knowledge and their most important communities in the world today, so in England, the East, Russia, and so on' ${ }^{10}$. The basic aim was to expand operations in the Italian and French circles, which was reflected in the postulates of reactivating (in the form of a station) of the Academy's Rome Expeditions and to reorganize the Polish post in Paris. The PAU Board hoped that the Polish authorities would support scientific stations through Polish diplomatic missions ${ }^{11}$.

On the occasion of his stay in France in 1921, Józef Piłsudski, the then Head of State, visited the Polish Library in Paris. Present along with Piłsudski were representatives of the French scientific world who - like

9 'tworzenie stacyj naukowych polskich, jako punktów oparcia dla poszukiwań czy badań naukowych lub wydatne poparcie i rozwinięcie tych, które już istnieją lub istniały, jak ekspedycja rzymska i stacja paryska Akademji Umiejętności; trzeba będzie pomyśleć o takich punktach oparcia w Anglji (zwłaszcza dla nauk przyrodniczych), w Petersburgu (dla badań historycznych), a może i gdzieindziej jeszcze'. S. Kutrzeba, Nauka a państwo, 'Nauka Polska' 1920, 3, p. 87.

10 ' $z$ uwzględnieniem wszystkich działów wiedzy i najważniejszych ich obecnie na świecie środowisk, więc w Anglji, na Wschodzie, w Rosji i t. d.’.

11 Archiwum Nauki PAN i PAU w Krakowie [hereinafter: ANPANPAU], Polska Akademia Umiejętności [hereinafter: PAU], Korespondencja Sekretarza Generalnego [hereinafter: KSG], ref. no. 438/20, document of 20 VI 1920. 
Poles - were among the advocates of the work of the Scientific Station in Paris. Its activities were combined with the perspective of broader ties between Polish and French science and culture. It was believed that the activities of the Station would also have a positive impact on political cooperation - thus the path to it was opened up by prestige on the scientific and cultural level. Piłsudski understood the influence of science or culture on the prestige of the independent Republic. This was confirmed by his later actions, when the National Culture Fund was established in 1928 in the new reality. It can be assumed that - already after the Polish-Bolshevik war - having the financial means to take wider actions against the Paris Station and to initiate new ones, Piłsudski and the Polish authorities would have undertaken the initiation of numerous scientific stations and their extensive program. However, these operations would not see their implementation. This resulted from the reality of the time - forced by the difficult financial situation of the Polish state. In the first period of independence, only the PAU Scientific Station in Paris and the associated Polish Library allowed for the achievement - although limited - of results in terms of prestige building ${ }^{12}$. An evolution in the approach of the Polish authorities to the Station emerged. More than just scientists began to see the potential source of prestige of Polish science - and thus, the country on the international arena - in its operations. The end of the struggle for borders made it possible, complicated by the poor financial situation of the state, to turn to cultural matters - based on appreciation of its multidimensional significance.

In February 1921, Poland formed an alliance with the French Third Republic. As a result, the role of the Science Station in Paris - which had an important cultural dimension - acquired political significance. The station created a broader ground for political and military cooperation. It built the prestige of Polish science in an allied country, facilitating the rapprochement of scientific circles - Polish and French - and, indirectly, of governments that placed scientific and cultural achievements in the political sphere. The significance of this role of the Station was special due to the strategic value of the alliance with France for Poland. Józef Piłsudski's visit to the Polish Library located in the French capital should also be seen in this context - the political dimension of the Station's work.

The Academy Board and the Polish authorities were interested in creating new stations. This was due to the positive results of the existing institution in Paris, which provided contact with the foreign scientific world. It provided French scholars with information about Polish scientific

12 J. Piskurewicz, Prima, p. 61. 
achievements - contributing in a natural way to the prestige of the reborn state. Thus, through the station, the PAU was able to influence Poland's relations with other countries, which also defined scientific contacts. Indirectly, the authorities of the Second Republic of Poland also gained this influence. Taking this into account, efforts were intensified in order to bring about the creation of a Polish facility in the Italian capital, similar in character. In 1927, the PAU Scientific Station in Rome was officially established $^{13}$. For the same reasons as the Paris facility, the Station built the prestige of Polish science in a reality defined by limited possibilities of action. There was even a risk of closure of the station in Rome as a result of the lack of government subsidies between 1930 and $1932^{14}$. In the end, the Station, where the library was particularly important, was not closed. Józef Michałowski was the caretaker of its collection. The Station hosted lectures by Polish and foreign scientists (mainly Italian), which allowed to increase the popularity of Polish science ${ }^{15}$. Like the analogous facility in France, the Station in Rome also built up contacts - in this case, in the Italian community - which could be exploited on a political level. Poland and Italy, countries with Catholic traditions, maintained correct relations during the discussed period, and the Station in Rome contributed to their development and, prospectively, to their strengthening.

During the period of the Second Republic of Poland, it was not possible to transform the Polish House in Vienna into another scientific station, whose property was taken over by the PAU in $1920^{16}$. The broadly conceived idea of creating stations in other cities was not realized either. To a large extent, this was a consequence of limited finances of the PAU and the Polish state - especially during the global economic crisis. The amounts for foreign operations were - in comparison with domestic expenditure on science - particularly high due to the costs of living and operating institutions in highly civilized countries. Despite these conditions, the operations of the existing facilities, especially the Paris Station - since the mid-1920s and in the following decade - brought positive results. In France, the prestige of Polish science was successfully built. Close relations between scientists from Poland and France made the Paris Station an important

13 Its establishment coincided with a period of increased interest of Italians in Polish issues in research. This interest was reflected in the form of lectures on Polish literature, inaugurated in 1923 at the University of Rome. D. Rederowa, op. cit., p. 129.

14 Ibidem, p. 84.

15 Ibidem, pp. 130-131.

16 Archiwum Akt Nowych [hereinafter: AAN], Poselstwo RP w Wiedniu, ref. no. 349, sheets 1,8 . 
element of the Polish foreign policy towards the Third Republic ${ }^{17}$. On the basis of the resolution of the Academy Board of Directors of 21 December 1934, a didactic center was established. The center, whose program was developed by the PAU delegate Franciszek Jan Pułaski, was attended by young Frenchmen dealing with Polish issues. It was a significant testimony to the rapprochement that took place in Polish-French relations at the scientific level. Thus, the Station in Paris fulfilled role the Polish authorities expected of it. However, the conditions were already different. France continued to be officially Poland's ally, but relations between the countries cooled down. Poland had legitimate concerns, especially since the Treaty of Locarno (1925), about the fulfillment of the allied obligations by the Third Republic. Simultaneously France looked distrustfully at the relaxation of Polish relations with Germany after Adolf Hitler came to power, which to a large extent was the result of the Polish belief in the decline of the value of the alliance of the Second Republic of Poland with the Third Republic. Thus, on a scientific level, relations between Poland and France were better than political relations. Polish science gained more and more recognition and interest in France, which was influenced by its prestige - co-created by the PAU. As a result, in the years of World War II, in the period preceding the German attack on the Third Republic, the lectures on Poland, which were organized by the French for their countrymen, were not stopped ${ }^{18}$.

After the establishment of the French Institute in Warsaw in 1925, a decision was made to reorganize the Polish Library in Paris. The reorganization was an initiative of the PAU - undertaken jointly with the Polish Ministry of Foreign Affairs - aimed at giving the Library an analogous framework for operations to that granted to the Institute ${ }^{19}$. Plans included adaptation of the Library to 'modern scientific and state needs' ${ }^{\prime 20}$. Thus, achievements on the scientific level appeared to be potentially beneficial for the prestige of the Polish state. In practice, the Library's activities gained a two-track character - scientific and informational. The library, which was given the title of a scientific institute, was assigned

17 J. Piskurewicz, Prima, p. 217.

18 D. Rederowa, op. cit., pp. 125-126.

19 Przemówienie wiceprezesa Jana M. Rozwadowskiego, 'Rocznik Polskiej Akademji Umiejętności' 1924/1925, pp. 49-50; The institute was involved in facilitating rapprochement between Polish and French scholars. It pursued this goal by supporting studies and scientific activities - both Polish and French. Subsidies were given to FrenchPolish scientific publishers and lectures on French literature, history and geography were organised. There were also French language courses. Kronika, 'Nauka Polska' 1927, 6, pp. 418-419.

20 After: J. Piskurewicz, Prima, p. 121. 
the task of collecting and publishing source materials concerning Poland. The Library's role was to stay in touch with representatives of the French scientific world. This was supported by lectures on Polish literature, history and art. The PAU was responsible for these strictly scientific activities. The informational operations consisted in passing on and providing access to various pieces of information about the Republic of Poland to French politicians and journalists. It also manifested in assigning library rooms for lectures, as well as lectures by politicians and publicists from Poland, who addressed social and political issues in their speeches. The informational scope of operations was dealt with by the MFA or the Polish embassy in Paris. The combination of scientific and informational works was a testimony to the cooperation between the PAU and the Ministry of Foreign Affairs. This showed the link between science and politics. It was understood that the recognition of the scientific achievements fostered by the Academy translated into strengthening the prestige of the reborn Republic in the international arena. Although the members of the Academy were in favor of building the prestige of independent Poland, they were not interested in deepening the links between science and politics. In connection with the reorganization of the Polish Library in Paris, the Ministry of Foreign Affairs provided an intermediary in obtaining state funds for the renovation of its building and budget. In 1929, the former Secretary General of the PAU, Stanislaw Wróblewski, and his successor in this position, Stanislaw Kutrzeba, agreed that after the renovation of the Library they would strive to become independent from the Ministry of Foreign Affairs. Guided by the good of science and distance to politics, they preferred contacts with the Ministry of Religious Denominations and Public Enlightenment ${ }^{21}$. The PAU needed the support of the Ministry of Foreign Affairs in building its prestige, but the relations with this ministry hampered the freedom of scientists who valued independence. The desire to become independent of the Ministry of Foreign Affairs was evidence of the tendency of the authorities to increase the scope of influence on scientific matters, which they intended to subordinate to the utilitarian interest of the state, rather than 'pure science'.

The role of the Academy's operations in relation to the French scientific community is also evidenced by the creation of a Polish section at the Slavic Research Institute, which operated since 1920 at the University of Paris ${ }^{22}$.

${ }^{21}$ Ibidem, pp. 123-124.

22 The institute was directed towards creating a European centre for Slavic studies. It was planned that it would be a centre conducting linguistic, historical, geographical, economic or political research. the majority of French scholars focused on Slavic issues were gathered at the Institute. The Institute was headed by Antoine Meillet, a professor 
The Academy not only approved the idea of creating the Section, but also presented its own vision of its organization. In a letter of 7 January 1923 to the Ministry of Foreign Affairs, the PAU authorities informed that the Section should combine 'purely scientific' work, such as the organization of lectures by Polish professors or the care of the Polish students of the French government, with 'practical and scientific' activities. As part of the practical and scientific activities, the PAU listed 'teaching French society about the current state of Poland in political, social and economic terms by means of lectures, readings, demonstrations, popularisation of relevant Polish scientific literature, providing the institute's library with necessary works or brochures' ${ }^{23}$. In mid-1923, the PAU officially joined the Slavic Research Institute - authorized by the Council of Ministers to represent the Polish authorities. This made it possible to organize the Polish Section, whose important task was to build the prestige of Polish science in the opinion of French society. Zygmunt Lubicz-Zaleski, supported by the Academy, became the Secretary General of the Section ${ }^{24}$. The authorities left the Section relative freedom to act, recognizing that scientists know best what they need to learn. The Academy's emphasis on the importance of 'practical and scientific' activities also led to such a position. However, also in this area one cannot speak of full freedom - it was limited by the interest of the state. The PAU acted as a representative of Polish authorities. When acting on behalf of the government, the Academy could not take a separate position on the activities of the Section.

The twelfth paragraph of the 1919 statute can also be said to refer to the issue of building the prestige of Poland in the international arena. This paragraph stated: 'For foreign scholars, the Academy will issue a separate bulletin, Bulletin international, in Latin or in one of the modern languages (English, French, German, Italian). The publication of a work in a foreign language in other publications of the Academy may be made by request of the relevant Department with the consent of the Academy Board, provided that the text of the work submitted by the author is completely correct

of the Collége de France. In the first period of the Institute's operations, there were three sections: Czech, Yugoslavian and - unofficially - Russian. While the Russian section was maintained by the French Ministry of Foreign Affairs, the Czech and Yugoslav governments supported the Russian section. Formally, however, the Institute was a French institution it received subsidies from the government of the Third Republic. Ibidem, pp. 63-64.

23 'pouczanie społeczeństwa francuskiego o obecnym stanie Polski pod względem politycznym, społecznym, ekonomicznym za pomocą wykładów, odczytów, pokazów, popularyzowania odnośnej literatury naukowej polskiej, zaopatrzenia biblioteki instytutu w potrzebne dzieła lub broszury'. After: J. Piskurewicz, Prima, p. 64.

24 D.H., Stosunki naukowe Polski z zagranica, 'Nauka Polska' 1925, 5, p. 395. 
in terms of language ${ }^{25}$. The publications allowed for the dissemination of knowledge about Polish scientific achievements. They also made it possible to learn about foreign achievements. Michał Siedlecki, who just like Władysław Konopczyński - discussed the issue of Polish science abroad at the 1st Congress of Polish Science, referred to the need to reach a wider circle of specialists. For this reason, he postulated the initiation of new periodicals on various subjects. These journals would be addressed to scholars in countries other than Poland. Siedlecki pointed out as the aim of this initiative his desire to show the world science the Polish achievements $^{26}$. Through its publishing activities, the Academy gained the opportunity to co-create the prestige of Polish science in the international environment on the next level.

In the Second Republic of Poland, the Academy sought to gather in its own publications information on the entire scientific output of the country's scientists - in order to present it to foreign audiences. This served to represent Polish science in relation to the foreign scientific community. However, the state of the publishing movement and the lack of closer cooperation with other scientific institutions in the country prevented the success of centralized PAU's procedures ${ }^{27}$. Nevertheless, the Academy continued to undertake and develop projects. The main publishing house that the Academy intended to exchange with other institutions after World War I was the Bulletin International de l'Académie Polonaise des Sciences et des

25 ‘Dla uczonych zagranicznych wydawać będzie Akademja osobny biuletyn, Bulletin international, w języku łacińskim, albo w jednym z nowożytnych języków (angielskim, francuskim, niemieckim, włoskim). Ogłoszenie pracy w obcym języku w innych wydawnictwach Akademji może nastąpić na przedstawienie odpowiedniego Wydziału za zgodą Zarządu Akademji, o ile tekst pracy przedłożony przez autora będzie pod względem językowym zupełnie poprawny'. Statut Polskiej Akademji Umiejętności, Kraków 1920, p. 6. In the 1924 Statute, the thirteenth paragraph concerned these matters: 'Dla zagranicznych uczonych Akademja wydaje sprawozdania, w których urzędowym językiem jest język francuski, prace zaś mogą ukazywać się w języku angielskim, francuskim, łacińskim, niemieckim lub włoskim. Ogłoszenie pracy w obcym języku w innych wydawnictwach Akademji może nastąpić na przedstawienie odpowiedniego Wydziału za zgodą Zarządu Akademji' ['For foreign scholars, the Academy issues reports in which the official language is French and the works may be published in English, French, Latin, German or Italian. The publication of the work in a foreign language in other publications of the Academy may be made by request of the relevant Department with the consent of the Academy Board']. Statut Polskiej Akademji Umiejętności, Kraków 1927, p. 9.

26 M. Siedlecki, Nauka polska na terenie międzynarodowym, 'Nauka Polska' 1920, 3, pp. 192-193.

27 K. Stachowska, Z działalności wydawniczej Polskiej Akademii Umiejętności - starania o upowszechnienie za granica polskiej myśli naukowej w latach 1873-1952, 'Rocznik Biblioteki PAN w Krakowie' 1973, 19, pp. 55-60. 
Lettres $^{28}$. The publishing house had been running series on mathematics and natural sciences. In 1929, the nature series was divided into two sections - botanical and zoological. This facilitated exchange with foreign specialist societies. Starting in 1926, only shorter works were published in the Bulletin. The longer ones were included in its 'Supplements', which were transformed into two series of the 'Mémoires' publications - also aimed at foreign audiences. Starting in 1928, the Academy managed a new magazine abroad - Comptes Rendus Mensuels des Séances de la Classe des Sciences Mathématiques et Naturelles, edited by Karol Dziewoński. While the Bulletin was published 3-4 times a year, Comptes Rendus was published once a month ${ }^{29}$. In 1930 Comptes Rendus Mensuels des Séances de la Classe de Médecine and the Bulletin International de l'Académie Polonaise des Sciences et des Lettres. Classe de Médecine were inaugurated. This was related to the establishment of the PAU Medical Department ${ }^{30}$. The publications played an important role in the Academy's building the prestige of Poland, because their exchange was the basic form of informing foreigners about scientific achievements $^{31}$. The international contacts of the PAU grew rapidly - in the

28 J. Piskurewicz, Prima, pp. 29, 58-59. This publishing house continued the traditions from before World War I. In the 1870s, the Academy authorities initiated the Bibliographische Berichte über die Publikationen der Akademie der Wissenschaften in Krakau. The main objective of Bibliographische Berichte was to inform the foreign scientific world about the works published by the Academy. The first notebook of this publishing house was published in 1876. Another one came after three years - at that time, the title was modified, adopting Literarische Mittheilungen und Bibliographische Berichte. The plan was to publish summaries of works in German and French. In practice, it was limited to German. Bibliographische Berichte did not survive the test of time. The initiative of publications directed by the Academy to the foreign community was resumed in the next decade. Starting in 1889, Anzeiger and Bulletin International were published. In fact, both periodicals - targeted at foreign audiences - were largely based on reports of the Academy translated from Polish. Anzeiger was dominated by German and Bulletin by French. After a few years, the two publications were merged into one. Later on, there were divisions - the Bulletin consisted of series devoted to particular branches of science. K. Stachowska, op. cit., pp. 44-46, 49, 52, 53.

${ }^{29}$ K. Stachowska, op. cit., pp. 66-68.

30 Ibidem, p. 68; D. Rederowa, op. cit., p. 88; J. Piskurewicz, Prima, p. 117.

31 This was also the case during the partitions - Danuta Rederowa pointed out that maintaining contacts with foreign science was one of the most important tasks of the Academy. It considered the exchange of publications to be particularly conducive to this objective. D. Rederowa, op. cit., p. 93. Even before 1914, the scope of the exchange of publications - conducted by the Academy with institutions all over the world - was significant. Several hundred institutions maintained contacts with the Academy in this matter. After the war, the exchange was stopped due to the disorganisation of the post office and international communication. The gradual overcoming of the difficulties by the Academy was the result of the intermediary of the Office of International Exchange of Publications, which existed at the library of the Ministry of Foreign Affairs. J. Piskurewicz, Prima, p. 58. 
mid-1920s, the Academy exchanged publications with 489 institutions, and in 1930 their number increased to 781 (they came from 47 countries). Within the 781 institutions, there were 68 academies of science and fine arts. In the $1937 / 1938$ academic year, the PAU received the largest number of books obtained through exchange, and the Academy received publications from 1197 scientific institutions $^{32}$. Nevertheless, some members of the Academy were sceptical about this form of building the prestige of the Republic. Kutrzeba, as Secretary General, pointed out that among foreign professionals in particular fields, there should be those who speak Polish and seek to learn about the findings of Polish scientific publications. He explained that Polish scientists learned foreign languages and sought access to information about scientific achievements in other countries ${ }^{33}$.

The desire to influence the international scholarly community is noted in the fourteenth paragraph of the 1919 Statute, which allows the Academy to have not only domestic but also foreign active members. The fifteenth paragraph provides for the appointment of domestic and foreign correspondent members. This created the possibility of direct contact with the activities of PAU, and thus Polish science, by scientists from other countries. Correspondent members - including foreign ones - were given the opportunity to participate in the PAU meetings. The right to receive Academy publications was also guaranteed. Paragraph seventeen of the Statute stated: 'The election of a foreign member, active or correspondent, requires the approval of the Government ${ }^{\prime 34}$. This provision showed the importance that the authorities attributed to the PAU's contacts with foreign scholars. The government had the option of rejecting the candidature, which it would see as unsuitable for Polish interests ${ }^{35}$. The Ministry of Foreign Affairs corresponded with Polish diplomatic missions in various countries - acquiring information about the candidates. In most cases, the diplomatic missions did not raise objections to candidates for foreign members ${ }^{36}$. The Ministry of Foreign Affairs forwarded information

32 D. Rederowa, op. cit., pp. 92-93.

33 J. Piskurewicz, Prima, pp. 117-118.

34 'Wybór członka zagranicznego, czynnego czy korespondenta, wymaga zatwierdzenia Rządu'. Statut Polskiej Akademji Umiejętności, Kraków 1920, pp. 7-9. These provisions were maintained in the 1924 Statute, although it was modified. The new statutes assumed that the election of a foreign active member or correspondent required the approval of the President of the Republic of Poland and not, as before, the government. Statut Polskiej Akademji Umiejętności, Kraków 1927, pp. 9-11.

35 Since the introduction of the new statute, this was decided by the President of the Republic of Poland, which further elevated the rank of this provision.

36 See for example: AAN, Ministerstwo Spraw Zagranicznych [hereinafter: MSZ], ref. no. 13436 , sheets $6-15,19-25,27-31,47,56,57,61,64-66$. 
on candidates - obtained from diplomatic missions and embassies - to the Ministry of Religious Denominations and Public Enlightenment ${ }^{37}$. The verification of potential foreign members of the Academy by the authorities through the Ministry of Foreign Affairs was another testimony to the importance of building the prestige of Polish science in the international arena. The goal was not to allow foreign members of the Academy to be scientists associated with the anti-Polish orientation or arousing other controversies. A shortcoming of this approach was the entry of current politics into the field of science. For the authorities, in the approval of foreign members, the evaluation criterion based on political rather than purely scientific considerations was decisive.

The importance of foreign members in building prestige was understood above all by the Academy, which resulted in a rapid increase in their number ${ }^{38}$. It was a testimony to the desire to strengthen the contact of global science with Polish works, as well as the desire to attract potential representatives at foreign scientific conventions. Jan Piskurewicz pointed out that in 1924, there were representatives of almost all European countries among the foreign members of the PAU. The United States was also represented ${ }^{39}$. This was not only scientific but also political, as evidenced by the membership of Raymond Poincaré (five-time prime minister, 1913-1920 President of France) and Arthur Balfour (1902-1905 prime minister of $\mathrm{UK})^{40}$. Within the PAU, a membership invitation to the Papal Nuncio in Poland - Achille Ratti (from 1922 on, Pope Pius XI) was considered $^{41}$. This association with the Academy of figures playing an important political role was particularly important from the perspective of the Polish authorities. Convincing a figure of recognized authority in Western Europe about the value of Polish culture opened up the possibility of gaining greater favor for the Second Republic among the societies of other countries. Polish culture appeared to be an integral part of universal culture, especially European. It was also an argument for rejecting views that questioned the legitimacy of the existence of the Polish state, particularly important in view of the theses proclaimed by Germany and

37 Ibidem, sheets $48,67,68$.

38 Jan Piskurewicz established that in particular in 1925-1930 there was a significant increase in the number of foreign members of the PAU. During this period, 48 new foreign members were elected. As a result, $1 / 3$ all foreign members who joined the Academy between 1919 and 1939 became members during this period. J. Piskurewicz, Prima, p. 105.

39 Ibidem, p. 19.

40 Poincaré became an active member on 12 May 1921 and Balfour on 15 June 1923. Skład Polskiej Akademji Umiejętności, 'Rocznik Polskiej Akademji Umiejętności' 1923/1924, p. VII.

41 J. Piskurewicz, Prima, p. 19. 
the Soviet Union about Poland as a seasonal state or an artificial creation of the Treaty of Versailles. The Polish authorities hoped that the Academy - by contributing to the shaping of Poland in international opinion as a country with an established national culture - would create a conviction of Polish legitimate needs and interests. For example, the justification of access to the sea by including part of Pomerania in the Second Republic of Poland was seen in these categories. The results of scientific research were presented, which were intended by the authorities but also by scientists to justify this affiliation ${ }^{42}$. On the initiative of Stanisław Kutrzeba - and under his editorship - a work entitled Historja Ślaska: od najdawniejszych czasów do roku 1400 [The History of Silesia: from the earliest times to the year 1400] was also published, which was intended to contribute to the justification of this land's relations with Poland ${ }^{43}$.

Poles living abroad could also be among the foreign active members. They included Maria Skłodowska-Curie and Władysław Mickiewicz with French citizenship and Aleksander Brückner with German citizenship ${ }^{44}$. The association with the Academy of figures of recognized authority in other countries was also supposed to build the prestige of Polish science outside the borders of the Second Polish Republic.

The new statutes of the Academy from 1924 - approved by the Council of Ministers three years later - introduced another provision. The fifth paragraph specified the tasks of the Academy. In the first paragraph, it was assumed that the PAU, in particular, 'has the task of preserving, securing and protecting the fruits of Polish creative scientific work and of making it accessible to the general public, as well as maintaining communication between Polish science and the foreign scientific world' 45 . In fact, the PAU had already carried out activities in this area - regardless of their official inclusion in the statute.

A form of building the prestige of Polish science on the international arena were scholarships and allowances granted by the PAU to scientists for the purpose of conducting foreign research or studies. In this way, scientists were able to learn about foreign scientific achievements. They

${ }^{42}$ See for example: Gdańsk. Przeszłość i teraźniejszość, ed. S. Kutrzeba, Lwów-WarszawaKraków 1928.

43 Historja Ślaska: od najdawniejszych czasów do roku 1400, vol. 1, ed. S. Kutrzeba, Kraków 1933.

${ }_{44}$ Brückner became an active member on 31 October 1891, Skłodowska-Curie on 21 May 1909 and Mickiewicz on 12 May 1921. Skład Polskiej Akademji Umiejętności, pp. II, IV, IX.

${ }_{45}$ 'ma za zadanie: owoce polskiej twórczej pracy naukowej utrwalać, zabezpieczać i chronić oraz nauce powszechnej uprzystępniać, tudzież utrzymywać łączność nauki polskiej ze światem naukowym zagranicznym'. Statut Polskiej Akademji Umiejętności, Kraków 1927, p. 4. 
could - on behalf of the Polish state - establish and expand cooperation with foreign researchers and centers. They also gained the opportunity to present the Polish scientific output - building the prestige of the Second Republic in the environment of scientists in other countries. However, the importance of scholarships and allowances granted by the PAU was greater before World War I. Following the war, it diminished due to the bad financial situation of the Academy ${ }^{46}$. The Academy also directed scholarships to foreign researchers dealing with issues concerning Poland. As a result, it increased its own prestige - showing its openness to foreign analyses concerning Polish affairs. The goal was to connect foreign scholars with Polish culture, to whose development they could contribute. Scientists from other countries could also spread a good opinion of Polish science in their own countries - thus contributing to the prestige of science, and indirectly the Polish state.

The role of national academies - not only the PAU - in building the prestige of independent states was particularly evident in the activities of the international scientific organizations - the Conseil International de Recherches and the Union Académique Internationale de Recherches et de Publications, established in 1919.

The American astronomer George Ellery Hale advocated the establishment of a scientific organization bringing together the countries that were part of the victorious coalition in World War I. This idea was welcomed in the world of science. A constituent assembly was convened, which led to the creation of the Conseil International de Recherches (the International Research Council). Two preparatory conferences were held in London (9-11 October 1918) and Paris (26-29 November 1918). National academies of the allied countries took part in them. The next step in the realization of Hale's idea was the meeting of the interim Executive Committee, organized from 20 to 24 May 1919 under the chairmanship of Émil Picard, a mathematician and lifelong secretary of the French Académie des Sciences (Academy of Sciences) ${ }^{47}$.

The constituent assembly that led to the creation of the International Research Council took place in Brussels and lasted from 18 to 28 July 1919. The meeting was hosted by the Académie Royale des Sciences, des Lettres et des Beaux-Arts de Belgique (Royal Belgian Academy of Sciences,

${ }^{46}$ On the other hand, foreign scholarships, whose beneficiaries were Poles, appeared on a larger scale. The scholarships were funded by governments of other countries or their citizens. D. Rederowa, op. cit., pp. 97-100.

${ }^{47}$ W. Natanson, Sprawozdanie tymczasowe z przebiegu zgromadzenia konstytucyjnego 'Rady Międzynarodowej Badań Naukowych' odbytego w Brukseli, w dniach od 18. do 28. lipca 1919 roku, Kraków 1919, p. 3; D. Rederowa, op. cit., p. 110. 
Literature and Arts). Sixteen countries were invited to Brussels for the constituent assembly: Belgium, Brazil, USA, France, UK, Australia, Canada, New Zealand, Union of South Africa, Greece, Italy, Japan, Poland, Portugal, Romania and the Kingdom of Serbs, Croats and Slovenes. Ultimately, representatives of nine countries took part in the Assembly: Belgium, France, Japan, Canada, New Zealand, Poland, USA, UK and Italy ${ }^{48}$. The subject of interest of the new organization was mathematical and natural sciences. The aim was to organize cooperation in the field of "pure science as well as its numerous practical applications in the fields of mathematics, astronomy, geodesy and geophysics, radiotelegraphy, physics, chemistry, biology and medical sciences, geology, geography and general bibliography ${ }^{\prime 4}$.

Poland's accession to the International Research Council was possible due to the support of Władysław Mickiewicz ${ }^{50}$, head of the PAU Scientific Station in Paris. In April 1919 the Academy was invited by the Executive Committee to represent the Polish state at a meeting in Brussels. In the following month - 12 May - the Academy sent a memorandum to the Ministry of Foreign Affairs and the Ministry of Religious Denominations and Public Enlightenment, in which it convinced the Polish government of the importance of the initiative to establish an international scientific organization, the Council ${ }^{51}$. The Academy asked for permission to represent Poland during the July session in the Belgian capital. It requested the government to cover the costs of Council membership (contributions and other expenses). The memorandum also asked for help in sending a delegate of the Academy to the meeting in Brussels, which was necessary in view of post-war communication difficulties. This delegate - as a consequence of the support of the Polish authorities - was to receive 'all authorizations and documents which would ensure his free passage through Paris to Brussels and return to Krakow, together with access to the Paris-Warsaw express train ${ }^{\prime 52}$. The Polish authorities ensured the Academy would have

48 Brazil, Australia, Union of South Africa and Greece had previously indicated that they would not send delegates to the constituent assembly in Brussels. Romania, Portugal and the Kingdom of Serbs, Croats and Slovenes originally reported that they would send delegates to the Brussels Assembly, but ultimately they did not. W. Natanson, op. cit., p. 5.

49 'czystej nauki jako też jej rozlicznych praktycznych zastosowań na polu matematyki, astronomji, geodezji i geofizyki, radjotelegrafji, fizyki, chemji, biologji i nauk lekarskich, geologji, geografji oraz bibljografji ogólnej'. Sprawozdanie Sekretarza Generalnego Prof. K. Kostaneckiego, ‘Rocznik Polskiej Akademji Umiejętności' 1918/1919, p. 70.

50 Ibidem.

51 W. Natanson, op. cit., pp. 3-4.

52 'wszelkie pełnomocnictwa i dokumenty, któreby zapewniły mu swobodny przejazd przez Paryż do Brukseli i napowrót do Krakowa wraz z dostępem do ekspresowego pociągu Paryż-Warszawa'. ANPANPAU, PAU, ref. no. I-157a, sheet 10. 
support. They saw an opportunity to create a new level of contact. At the same time, key political decisions were made, culminating in the signing of the Treaty of Versailles on 28 June $1919^{53}$. It can therefore be assumed that the Polish government saw the Congress as a form of creating a new order in science, too. This order was based on new foundations, so that Polish science - so far underestimated or included in the achievements of the partitioning countries - could play an important role. The way to do this was through involvement in international organizations. Władysław Natanson, professor of physics at the Jagiellonian University, became a delegate to the meeting in Brussels.

In the 'Sprawozdanie tymczasowe $\mathrm{z}$ przebiegu zgromadzenia konstytucyjnego 'Rady Międzynarodowej Badań Naukowych', odbytego w Brukseli w dniach od 18. do 28. lipca 1919 roku' ['Interim Report on the constituent assembly of the 'International Research Council', held in Brussels from 18 to 28 July 1919'], which was published by the Academy, Władyslaw Natanson informed that at the preparatory conferences, it was decided that the governments of individual countries should be represented by the national academies in the Assembly and then in the Council. However, it was obvious that governments, including the Polish one, would want to act through national academies, because, as it later turned out, scientific matters were gaining political significance.

Finally, it was taken into account that not all countries had national academies, and in some countries the opposite, more than one, which was a risk of conflict when selecting the one to represent the country on the International Research Council. For this reason, it was assumed that countries could be represented on the Council not only by national academies (which was preferred), but also by specially created 'national research councils', other institutions or directly by governments ${ }^{54}$. The term 'national' functioned internationally as a synonym for 'state'. The names used were 'national' or 'nations' because the notion of a nation had an emotional content, and the idea of the state as such did not evoke such emotions. This can be proved by the assembly of the League of Nations in which states were represented. However, in the case of nations without their own statehood - which was Poland until 1918 - the term

53 At the peace conference in Paris, the issues of Polish politics and science were intertwined in the activities of the Office of Congress Work of the Ministry of Foreign Affairs, where scholars such as Władysław Konopczyński and Stanisław Kutrzeba were present as experts. See more: W. Konopczyński, Dziennik 1918-1921, part 1, eds. P. Biliński, P. Plichta, Warszawa-Kraków 2016.

${ }^{54}$ W. Natanson, op. cit., p. 8; Sprawozdanie Sekretarza Generalnego Prof. K. Kostaneckiego, p. 71. 
'national' functioned separately ${ }^{55}$. It was associated with the culture and language of the dominant nationality, which gave rise to conflicts at a time when nationalistic tendencies were growing. This issue also occurred in the practice of the activities of the National Culture Fund, in particular in the form of attacks on Stanisław Michalski's policy ${ }^{56}$. A broader, but analogous problem was the definition of science in individual countries - the term 'Polish science' could be interpreted in state but also national categories. This was especially true for the research of the natural and geological resources of the country, as well as its history and culture. Despite the popularity of congress languages, the role of Latin expired in the 19th century - national languages dominated in publications instead. The policies of individual governments supported the accentuation of differences, and the scientific community did not forget what science has in common. Thus, there was a level of divergence in the approach of scientists and politicians. It did not involve making scientists independent from politicians, from whom they needed material support. This was all the more so because, as far as Poland was concerned, scientists, guided by patriotism, also saw political benefits for the countries they represented in their scientific achievements. In this context, the issue of the Council took on a major importance - opening up new dimensions of scientific development.

The International Research Council was not intended to be limited to countries that were represented at the Brussels Constituent Assembly. The decision to accept further members was dependent on the will of individual governments. At the July meeting in Brussels, it was decided to invite more countries - China, Siam, Czechoslovakia, Argentina, Chile, Mexico and Monaco - to the Council. Countries that remained neutral during World War I - Denmark, Spain, the Netherlands, Norway, Sweden and Switzerland - were invited. The openness of the Council made the number of its members grow. In 1931, 41 countries were represented on the Council ${ }^{57}$.

The Council's initiative opened up an opportunity for national academies to build the prestige of the countries they represented. The PAU gained the opportunity of establishing closer contact with other

55 An example of a statement by a recognised historian, Marceli Handelsman Uniwersytet Warszawski. Z racji pierwszej rocznicy wskrzeszenia Wszechnicy Warszawskiej, 'Świat' 1916, 47. Handelsman postulated the establishment, after the evacuation of the Imperial University of Warsaw (7 July 1915), of a 'National University'.

56 J. Piskurewicz, W stużbie nauki i oświaty. Stanisław Michalski (1865-1949), Warszawa 1993, pp. 125-132.

57 Idem, Prima, p. 50. 
academies and scientific circles, which facilitated building the prestige of Polish science. The presence of the PAU in the Council was also important for other reasons. During the partitions, Polish science was dependent on the partitioning countries, which hindered its development-including the popularization of its own achievements in the international arena. During the First Congress of Polish Science, Michał Siedlecki and Władysław Konopczyński drew attention to this ${ }^{58}$. According to Konopczyński, it was necessary for scientific organizations - supported by funds from society and the state - to take action in the field of foreign relations of Polish science. He considered the impact of Polish science on foreign countries

58 According to Siedlecki: ‘Nasze warunki rozwoju w czasach niewoli były wprost antytezą tego, co miały kraje zachodnie. Mieliśmy zupełnie związaną swobodę ruchu, nie mogliśmy zetknąć się z szerokiemi zagadnieniami przez własne władze i własne państwo. Wielkie naukowe poczynania międzynarodowe odbywały się bez nas lub tylko z niewielkim udziałem naszych uczonych, pracujących pod obcą flagą. Środki do badań zdobywaliśmy nieraz niemal że ukradkiem, lub z wieloma trudnościami, a obce kraje nie mogły też na nas oddziaływać w takim zakresie, jakby to było dla nas pożyteczne' ['Our conditions of development in captivity were a direct antithesis of what Western countries had. Our freedom of movement was completely restricted, we had no contact with the broad issues because of our own authorities and our own state. The great scientific activities of the international community took place without us or with only a small participation of our scientists, working under a foreign flag. We often obtained the means for research almost secretly, or with many difficulties, and foreign countries could not influence us as much as it was useful for us']. M. Siedlecki, op. cit., p. 189. In Konopczyński's opinion: 'Nauka polska, spychana w cień przez rządy zaborcze, nie mogła nawet występować pod własnym znakiem; musieliśmy na zjazdach międzynarodowych figurować, jako Austrjacy, Rosjanie lub Niemcy, w delegacjach lub instytucjach, noszących firmę obcej narodowości. Działa się krzywda imieniu polskiemu, a my tę krzywdę jeszcze pogłębialiśmy, zaniedbując kontakt $\mathrm{z}$ nauką zagraniczną $\mathrm{w}$ obawie, że ona policzy owoc naszej pracy na dobro kultury rosyjskiej lub niemieckiej. Oduczaliśmy się czerpać bezpośrednio z krynic kultury zachodnio-europejskiej; czytywaliśmy dzieła francuskie, angielskie i włoskie w przekładach rosyjskich i niemieckich. Nas mało kto czytał, prawie nikt nie tłumaczył. Zbiorowe przedsięwzięcia powstawały bez naszego udziału, nawet gdy traktowały o Polsce. My sami przywykliśmy obcować tylko z małym kręgiem czytelników. Obustronna ignorancja wzajemna rozdzielała Polskę i Europę' ['Polish science, pushed into the shadows by the invading governments, could not even appear under its own flag; we had to appear at international conventions as Austrians, Russians or Germans, in delegations or institutions carrying a foreign nationality. The Polish name was being hurt, and we further aggravated this hurt by neglecting contact with foreign science for fear that it would count the fruit of our work for the benefit of Russian or German culture. We learned to draw directly from the critiques of Western European culture; we read French, English and Italian works in Russian and German translations. Few of us read, almost nobody translated. Collective undertakings were created without our participation, even when they concerned Poland. We ourselves became only used to dealing with a small circle of readers. The mutual ignorance divided Poland and Europe']. W. Konopczyński, Nauka, pp. 197-198. 
as one of the objectives of these activities ${ }^{59}$. Due to its importance and traditions, the PAU was predestined for this role. As a consequence of the Bolshevik coup, Russia found itself in isolation. The central states Germany and Austria-Hungary - were not represented in the Council as they were on the losing side. In particular, the French and Belgians opposed Germany's accession to the Council and even the scientific associations of other countries with the Weimar Republic ${ }^{60}$. Given the well-established status of German science, this can be seen as part of the struggle against competition, and thus, a desire for greater renown. On the other hand, however, it was remembered that the Germans used scientific achievements in practice - creating the military power of the state. The impact of politics on science emerged, which opened up new opportunities for the Academy to emerge from the shadow of the achievements of the former partitioners. The government expected the Academy to use the circumstances to gain prestige on the international arena. The Polish authorities understood that there was not a permanent, but a temporary weakening of Germany and the USSR, which were striving at various levels to break the isolation they found themselves in.

The assumption of temporary weakening of Poland's opponents was fully justified. The change of attitude towards German scholars was also influenced by political events - the conference in Locarno (1925) and the admission of Germany to the Council of the League of Nations (1926). In the year of the Weimar Republic's admission to the League, the Conseil International de Recherches invited Germany, Austria, Bulgaria and Hungary to join. Hungary and Bulgaria accepted the invitation ${ }^{61}$. Interestingly, in a letter of 9 April 1925, the Ministry of Foreign Affairs informed the PAU 'that it is in principle in favour of Germany's admission

59 W. Konopczyński, Nauka, p. 198.

${ }^{60}$ Natanson referred to the proceedings in Brussels: 'Tendencją Zgromadzenia, wielokroć razy wyrażaną publicznie, było: odgrodzić się od Niemców; we wszystkich zakresach Wiedzy obejść się bez Niemców' ['The tendency of the Assembly, repeatedly expressed in public, was to separate ourselves from the Germans; to do without Germans in all areas of Knowledge']. During a farewell address to the participants, the President of the Constituent Assembly, French mineralogist and geologist, Professor Alfred Lacroix, said: 'zbudowaliśmy tutaj gmach, do którego wstęp Niemcom jest wzbroniony' ['we have built an edifice here which Germans are prohibited to enter']. Belgian botanist and physiologist Auguste Gravis from the Académie Royale des Sciences, des Lettres et des Beaux-Arts de Belgique informed that the Academy has removed the German members. $\mathrm{He}$ also announced that it led to the severance of relations with German academies, universities and institutions. Gravis declared that the Belgian Academy would not take part in meetings where Germany was represented. W. Natanson, op. cit., pp. 26-27.

${ }_{61}$ D. Rederowa, op. cit., p. 110. 
to the International Union of Academies' ${ }^{\prime 2}$. It was another international organization - the Union Académique Internationale de Recherches et de Publications (the International Union of Academies) - which brought together national academies. However, the Ministry of Foreign Affairs did not take a categorical stance - considering it a priority to work out a common position between the PAU and French academies on the question of German membership. It was clearly recognized that the prospect of a German presence on the Council of the League of Nations was the primary threat. In scientific matters, the Ministry of Foreign Affairs made it a priority to prevent discrepancies between Polish and French scientists.

The objectives of the International Research Council were to facilitate the creation of special Unions within that organization. The Constituent Assembly in Brussels created the following Unions: Mathematics, Astronomy, Geodesy-Geophysics, Physics, Radiotelegraphy, Chemistry, Biology and Medicine, Geography, Geology and Technical Science. The unions had separate statutes - they could consist of sections. The general objective of the Unions was to support research and to lead to progress in scientific research within the various scientific fields. The unions provided contacts and cooperation opportunities for the international learning community - for example, by organizing congresses. They also supported the creation of new institutions, studios or departments, and initiated publishing activities. The support for publishing activities was linked to information on the results of research conducted in individual countries. There is no fixed date and venue for Union Assemblies. The Unions thus had the freedom to decide, unlike the supreme authority of the new organization, the Council's General Assembly, which was planned to take place every three years in Brussels ${ }^{63}$. In the absence of a Union for certain areas, the Council was empowered to arrange cooperation between nations within them. At that time, this cooperation did not take place within any Union. In order to design research and carry out other scientific undertakings, the Council was granted the right to establish relations with national academies and governments of the countries that were among its members ${ }^{64}$.

The Unions that were part of the Council allowed for building the prestige of individual countries in the areas they represented ${ }^{65}$. In the

62 ‘że zajmuje w zasadzie stanowisko przychylne dopuszczeniu Niemiec w skład Międzynarodowego Związku Akademji'. ANPANPAU, PAU, ref. no. I-157a, document of 9 IV 1925.

63 W. Natanson, op. cit., p. 7. Between the General Assemblies, the Executive Committee was in charge. Ibidem, p. 12; J. Piskurewicz, Prima, p. 50.

${ }_{64}$ W. Natanson, op. cit., p. 6.

65 Ibidem, pp. 13-20. 
work of the Unions, the building of prestige was combined with politics, which is noticeable in their initial anti-German orientation. The Brussels Constituent Assembly recognized that the work of the Physics Union would benefit from 'publishing bibliographic, reporting (i.e. referring) and synthetic (monographic) journals to replace similar German publications' ${ }^{\prime 66}$. Within the Chemistry Union it was noted 'that even in Spain, in South America, in China, German chemistry books have come into use; that German chemical literature paves the way for German trade and industry; that these works, textbooks, monographs, report journals and so on, are sometimes biased and unfriendly to foreign works. It was agreed that the German influence should be eliminated in all chemical science activities' ${ }^{\prime 67}$. For this reason, make reference was made to the need to publish French and English works in the field of chemistry, which would replace the treatises prepared by German authors.

The condition of being a member of an individual Union was the creation of special national committees, 'whose main task would be to develop Polish proposals for the Congresses. They would also monitor in the future whether and how much this method of scientific cooperation met the interests and needs of Polish science ${ }^{\prime 68}$. Until 1924, however, the Academy did not initiate committees ${ }^{69}$. Their tasks were performed by the Department of Mathematics and Natural Sciences of the PAU ${ }^{70}$. A success achieved in building the prestige of the Second Republic of Poland, possible due to the Academy's involvement in the Council, was the organization of the Congress of the Union of Pure and Applied Chemistry in Warsaw and Krakow, which took place from 4 to 14 September 1927. The direct initiator was the Polish National Committee for Chemistry ${ }^{71}$.

\footnotetext{
66 'wydawanie czasopism bibliograficznych, sprawozdawczych (czyli referujących) oraz syntetycznych (monograficznych), celem zastąpienia podobnych niemieckich wydawnictw'. Ibidem, p. 16.

67 'że nawet w Hiszpanji, w Ameryce południowej, w Chinach niemieckie książki chemiczne weszły w użycie; że literatura niemiecka chemiczna toruje drogę niemieckiemu handlowi i przemysłowi; że owe dzieła, podręczniki, monografje, czasopisma sprawozdawcze itp. bywają stronne i dla obcych prac nieżyczliwe. Zgadzano się na to, że trzeba dążyć do wyrugowania wpływu niemieckiego we wszystkich działaniach nauk chemicznych'. Ibidem, pp. 17-18.

68 'których głównem zadaniem będzie opracowywanie na kongresy polskich wniosków. One też pilnować będą w przyszłości, czy i o ile ten sposób naukowej współpracy odpowiadać będzie interesom i potrzebom nauki polskiej'. Sprawozdanie z wydawnictw i czynności Polskiej Akademji Umiejętności od czerwca 1924 do czerwca 1925, 'Rocznik Polskiej Akademji Umiejętności' 1924/1925, p. 35.

69 Ibidem, pp. 34-35.

70 J. Piskurewicz, Prima, p. 53.

71 Ibidem, p. 106.
} 
This first international chemistry convention in Poland was attended by 130 delegates representing 18 countries $^{72}$.

In his report, Natanson reported that as a consequence of the efforts of the French Académie des Inscriptions et Belles-Lettres (Academy of Inscriptions and Literature), efforts were made to lead to the creation of another international scientific organization, the Union Académique Internationale de Recherches et de Publications. The aim of the Association was to cooperate with its members in research and publications in the field of philosophy, philology, history, as well as moral and social sciences. It was assumed that this would contribute to scientific progress. The national academies present in the Union - possibly associations or other scientific institutions - were entitled to submit proposals for the organization's draft work program ${ }^{73}$. The Union carried out activities similar to those of the Conseil International de Recherches. The main difference was that the subject of the Association's activities was the humanities. The Academy was invited to the Association in which it represented Poland ${ }^{74}$. At the first conference of the International Union of Academies, held from 15 to 18 October 1919 in Paris, the following countries were represented: Belgium, Denmark, France, Greece, the Netherlands, Japan, Russia (emigrants), USA, UK, Italy and Poland. Thus, the Union was another initiative inspired by the states of the winning coalition, which allowed countries that remained neutral in war. The Union, like the Council, was initially lacking the former central states. This changed in the following years - in 1935, Germany and Austria were admitted to the Union ${ }^{75}$. It was envisaged that the Union Committee (General Assembly) - created by the delegations - would meet at least once a year. The Committee defined the directions of activities undertaken, decided on the admission of new members to the Union, amendments to the Statutes and on finances. The Committee was responsible for the election of the Union's Management Board. The Management Board was elected for three years to take care of the research and administrative work. Each of the countries present in the Union Académique Internationale de Recherches et de Publications is entitled to be represented by two delegates. At the conference in Paris, the PAU representatives were Kazimierz Morawski and Jan Michał Rozwadowski. Morawski, a classical philologist and historian, was President of the PAU

72 J. Róziewicz, H. Róziewicz, op. cit., p. 365.

73 Kronika, 'Nauka Polska' 1919, 2, p. 607; Sprawozdanie Sekretarza Generalnego Prof. K. Kostaneckiego, p. 72.

74 W. Natanson, op. cit., p. 25.

75 After the anschluss of Austria the country was represented by Germany in the Union. D. Rederowa, op. cit., p. 116. 
and Rozwadowski was director of its Department of Philology ${ }^{76}$. Both were professors at the Jagiellonian University.

During the Second Republic of Poland, the vice-presidents of the Board of the Union were Fr. Konstanty Michalski and Jan Michał Rozwadowski. In 1938, Stanisław Kutrzeba was confidentially encouraged to take up the post of Secretary of the Union. But Kutrzeba was not interested in the idea ${ }^{77}$. According to Danuta Reder: 'The PAU's contribution to the work of the Union was significant. In addition to the representation of England, Belgium, Denmark, France, the Netherlands, Japan, Norway, Italy and the United States, the PAU was part of a group of delegations which presented and initiated the current work of the Union, carrying out systematic research and preparing publications, taking a lively part in international undertakings in the field of philosophy, philology, classical archaeology and international law ${ }^{\prime 78}$. The author also noted that 'among the Slavic countries belonging to the Union, only Polish scholars designed ongoing works of the Union'79.

Both the Council - from 1931 as the International Council of Scientific Unions (the Conseil International des Unions Scientifiques) and the Union expanded their membership in the following years. In the case of Poland, the problem was the costs associated with membership in both organizations. Since 1922, represented by the PAU, Poland had been involved in the Council only within the Astronomy, Mathematics and Chemistry Unions. This was not because of a lack of willingness, but because of financial difficulties. These difficulties could not be resolved by the Academy, and the state authorities had other priorities in view of the poor economic situation. The changes were gradual - in 1922, the Academy represented Poland in the Astronomy, Mathematics and Chemistry Unions. In the following year it joined the Physics and Biology Unions, and from 1924 on, it was present in the Geodesy and Geophysics, as well as the Geography Unions ${ }^{80}$. The costs resulting from the participation in international meetings, conventions, congresses and

76 Sprawozdanie Sekretarza Generalnego Prof. K. Kostaneckiego, p. 72.

77 D. Rederowa, op. cit., p. 118.

78 ‘Wkład PAU w prace Unii [Związku] był znaczny. Obok reprezentacji Anglii, Belgii, Danii, Francji, Holandii, Japonii, Norwegii, Włoch i St. Zjednoczonych PAU znajdowała się $\mathrm{w}$ grupie delegacji, które przedstawiały i inicjowały bieżące prace Unii [Związku], prowadząc systematyczne poszukiwania badawcze i przygotowujące prace wydawnicze, biorąc żywy udział w przedsięwzięciach międzynarodowych w zakresie filozofii, filologii, archeologii klasycznej i prawa międzynarodowego'. Ibidem, s. 119-120.

79 'wśród państw słowiańskich należących do Unii [Związku], jedynie uczeni polscy projektowali bieżące prace Unii [Związku]'. Ibidem.

${ }^{80}$ Ibidem, pp. 112-113. 
conferences limited the Academy mainly to involvement in the Council and the Union. In other international conventions or congresses it took part - through its delegates - sporadically. Nevertheless, it was interested in the composition of official Polish delegations, which the government directed to congresses and conferences. The Academy was concerned about the government's lack of reliance on the opinions of scientific institutions to establish delegations to foreign conventions. For this reason, in 1923, the PAU addressed the Ministry of Religious Denominations and Public Enlightenment, the Ministry of Foreign Affairs and the Presidium of the Council of Ministers with a request to take action - in order to avoid possible negative consequences associated with the posting of incompetent persons ${ }^{81}$. The preferred pattern in government circles was communication regarding delegates between the MFA and the PAU. Then, on the initiative of the Ministry of Foreign Affairs, individual diplomatic missions were to provide support to the delegates who arrived. The diplomatic missions were informed by the delegates of possible public appearances or press releases of a political nature. Then the content of such a speech or article had to be agreed with the diplomatic mission. In this way, the authorities had a direct influence on political issues - related to the scientific activities under the patronage of the Academy ${ }^{82}$.

The focus on the Council and the Union proved the importance attributed to both organizations, whose meetings were attended by the PAU delegates. On the other hand, by participating in the Council and the Association, the Academy could count on the reimbursement of its costs ${ }^{83}$. The Polish authorities committed themselves to this ${ }^{84}$. Regardless of the

81 Three years later, in 1926, the PAU presented a draft to the Council of Ministers, in which it referred to its own solutions concerning the composition of Polish representations at foreign conventions, congresses, conferences and scientific and technical expeditions. Ibidem, pp. 95-96. The Academy's procedures resulted, albeit not immediately, in the authorities agreeing on the composition of government delegations to international scientific conventions with the PAU. J. Piskurewicz, Prima, p. 54.

82 ANPANPAU, PAU, ref. no. I-157.

83 J. Piskurewicz, Prima, pp. 53-54. See also data on the representation of Poland by PAU delegates and other scientists at international scientific conventions held in 19191925. Kronika, 'Nauka Polska' 1927, 6, pp. 402-412.

84 State aid for the Academy's international activities was not always without complications. In 1926, the PAU had to spend its own resources on activities in this area. Sprawozdanie Sekretarza Generalnego z czynności Polskiej Akademji Umiejętności za czas od czerwca 1925 do czerwca 1926, 'Rocznik Polskiej Akademji Umiejętności' 1925/1926, p. 66. Generally, however, the PAU could count on help from the authorities - in 1927, the subsidies provided to represent Poland in the Council and the Union were increased. Sprawozdanie Sekretarza Generalnego Polskiej Akademji Umiejętności za czas od czerwca 1926 do czerwca 1927 r., 'Rocznik Polskiej Akademji Umiejętności' 1926/1927, pp. 50-51. 
restrictions on work in the Council and the Union, the role of the PAU in building the prestige of the Republic on the international stage was crucial. As early as at the First Congress of Polish Science in 1920, Władysław Konopczyński said that the PAU was indeed entitled to represent Polish science abroad ${ }^{85}$. The PAU was responsible primarily for building the prestige of Polish scientific achievements in the international scientific community. Its presence in the Council and the Union was a means to achieving that end. PAU's activities facilitated the development of Polish science - they were also an element of foreign policy. For this reason, state authorities agreed with the PAU on science-related issues, which were linked to foreign policy. For example, in the early 1920s, the PAU wanted to obtain an opinion on the Latvian government's project to initiate a joint action in the scientific and cultural field involving Poland ${ }^{86}$. The scientists understood the importance of the PAU for the authorities.

During the 1st Congress of Polish Science, Michał Siedlecki, Władysław Konopczyński and Stanisław Kutrzeba postulated that Poland should officially join international scientific associations ${ }^{87}$. This led to a resolution of the Council of Ministers of 12 May 1921. In this resolution, the Academy was officially authorized 'to represent Polish science on behalf of the Polish State in international scientific associations ${ }^{\prime 88}$. This was a realization of the earlier efforts of the PAU - supported by the Ministry of Religious Denominations and Public Enlightenment - which as a result of the resolution officially joined both organizations ${ }^{89}$. However, when representing the state, the Academy had to take into account the interest of the authorities, which recognized the primacy of utilitarian interests of the state. In the following years, the PAU's involvement in the Council and the Union increased - thus the importance of both organizations in building the prestige of Polish science on the international arena grew ${ }^{90}$.

85 W. Konopczyński, Nauka, p. 199.

86 ANPANPAU, PAU, KSG, ref. no. 75/21, document of 4 II 1921.

87 In Siedlecki's opinion: 'Polska musi wystąpić jako państwo, musi okazać, że dba o rozwój światowej wiedzy narówni z innemi narodami' ['Poland must act as a state, it must show that it cares about the development of world knowledge as much as other nations']. For Siedlecki, this was linked with officially joining the Council and the Union. M. Siedlecki, op. cit., p. 195. See also: W. Konopczyński, Nauka, p. 200; S. Kutrzeba, op. cit., pp. 86-87.

88 'do reprezentowania nauki polskiej imieniem Państwa Polskiego w międzynarodowych związkach naukowych'. ANPANPAU, PAU, ref. no. I-157a, MWRiOP do PAU - 15 VI 1921; PAU, KSG, ref. no. 496/21, MWRiOP do PAU - 15 VI 1921.

89 Sprawozdanie Sekretarza Generalnego Prof. K. Kostaneckiego, pp. 73-74.

90 In 1924, the Secretary General of the PAU - Stanisław Wróblewski - decided that 'zacieśniają się węzły, łączące nas ze światowemi organizacjami naukowemi, rozszerza udział Polski w pracach rozrastających się Unij międzynarodowych, a niejeden już pomysł 
In December 1920, at the Assembly of the League of Nations, a discussion was held on the establishment of an international organization to foster intellectual cooperation. Reflections in this regard continued in March and September of the following year - at meetings of the Council of the League of Nations. The result was a resolution of the Assembly of the League of 21 September 1921, which expressed the wish to establish an organization to facilitate international cooperation in the scientific and cultural dimension. This led to the creation of Commission Internationale de la Coopération Intellectuelle (the International Commission for Intellectual Cooperation) - set up by the Council of the League of Nations on 15 May 1922. The initiative to create the Commission was taken by Belgium and France, countries that were most interested in building the prestige of their own countries on the scientific level - at the expense of Germany, defeated in World War I. It was agreed that the Commission would have a maximum of 12 members, including women ${ }^{91}$. Oskar Halecki, a historian, was elected the Secretary of the Commission. Maria Skłodowska-Curie became one of the members ${ }^{92}$. The presence of Skłodowska-Curie gave the Academy the opportunity to influence the work of the International Commission for Intellectual Cooperation ${ }^{93}$. National commissions were set up in each country to mediate between the newly established organization and institutions (including academies) and the scientific community ${ }^{94}$. Finally, the Academy decided to create a new body - the Polish Commission for International Intellectual Cooperation (until 1924, Commission for the

uczonego polskiego zdołał wywalczyć sobie uznanie na tym terenie, tak trudnym do zdobycia' ['the ties connecting us with the world's scientific organisations are tightening, expanding Poland's participation in the work of the growing international Union, and many ideas of Polish scientist have already managed to win recognition in this area, so difficult to obtain’]. Sprawozdanie Sekretarza Generalnego z czynności Polskiej Akademji Umiejętności za czas od czerwca 1923 do czerwca 1924, 'Rocznik Polskiej Akademji Umiejętności' 1923/1924, p. 51.

91 Kronika zagraniczna, 'Nauka Polska' 1923, 4, p. 505. The number of members gradually increased - in 1937 there were nineteen. J. Muszkowski, Międzynarodowa wspótpraca intelektualna wczoraj i dziś, 'Życie Nauki. Miesięcznik Naukoznawczy' 1947, 3, 13-14, p. 11.

92 J. Piskurewicz, Prima, p. 55.

93 Skłodowska-Curie was the author of a memorandum on the situation of science in Poland. One of the institutions that advised the Polish Nobel Prize winner in formulating theses on how to support science in Poland was the PAU. Apart from the PAU, an important role was played by the Józef Mianowski Fund. Skłodowska-Curie also received data from Polish universities and scientific societies. The memorandum she prepared was sent by the Commission to the League of Nations. Kronika zagraniczna, 'Nauka Polska' 1923, 4, p. 506; A. Rafalska-Łasocha, Maria Skłodowska-Curie i jej kontakty ze środowiskiem krakowskim, Kraków 2015, p. 135.

94 D. H., op. cit., p. 404. 
League of Nations), in which it became involved ${ }^{95}$. The Polish Commission did not become an important tool for the Academy in building the prestige of Polish science. It informed the world about the state of science in the country and provided information to the Republic of Poland about its organization in other countries. However, some members of the PAU kept their distance from this initiative. In a letter from 30 June 1923 to the Ministry of Religious Denominations and Public Enlightenment, Secretary General Stanisław Wróblewski stated that 'the Commission will not do much and that this attempt to justify the raison d'être of the current League of Nations will not lead far; nevertheless, I believe that Poland cannot, in these attempts, remove itself from participation' ${ }^{\prime 6}$.

Despite this distance, in June 1926, one month after the May Coup, the Congress of the National Commissions for Intellectual Cooperation of Eastern European Countries was held in Warsaw. During the preparations for the convention, it turned out that the organizers expected financial support from the Ministry of Foreign Affairs. Scientists understood that the convention could be used in the interest of building the prestige of the state through the professional organization, so they counted on money from the ministry ${ }^{97}$. The Ministry was considering a speech by the Minister of Foreign Affairs, but this idea was abandoned because of fears of creating the impression that the authorities were seeking to politicize the convention, which could be negatively perceived by other countries ${ }^{98}$.

Before the congress, the Scientific Council of the Ministry of Foreign Affairs met on June 19. President of the PAU Jan Michał Rozwadowski and Secretary General Stanisław Wróblewski were present at the meeting as representatives of the Academy. Among the participants were also delegates of other societies and senior officials of the Ministry of Foreign Affairs, as well as a delegate of the Ministry of Ministry of Religious Denominations and Public Enlightenment. During the meeting, the Minister of Foreign Affairs, August Zaleski, referred in his speech to the importance of relations on the scientific level between Poland and other countries. The Minister presented the action plan of the Scientific

95 See more: A.M. Brzeziński, Polska Komisja Międzynarodowej Wspótpracy Intelektualnej (1924-1939), Łódź 2001. For more information on intellectual cooperation within the League of Nations, see: idem, Organizacja i formy międzynarodowej wspótpracy intelektualnej w ramach Ligi Narodów (1922-1939), 'Przegląd Zachodni' 2015, 3.

96 'że Komisja nie zdziała wiele i że ta próba uzasadnienia racji bytu obecnej Ligi Narodów nie doprowadzi daleko; mimo to jednak sądzę, że Polska nie może przy tych usiłowaniach usuwać się od współudziału'. After: J. Piskurewicz, Prima, p. 57.

97 AAN, MSZ, ref. no. 13430, sheets 11-13.

98 AAN, MSZ, ref. no. 13431, sheet 9. 
Council of the Ministry of Foreign Affairs ${ }^{99}$. Zaleski said that the current government wants to base its actions on an in-depth opinion of the scientific community'100. He drew attention to several issues that required scientific justification. He pointed out, among other things, the issue of the Polishness of the so-called Gdańsk (Pomeranian) corridor, as well as the need to justify a permanent place for Poland in the League of Nations. Zaleski referred to the role of the Scientific Council at the Ministry of Foreign Affairs in the establishment of international scientific contacts by Poland. The Council was thus a kind of element of supervision and even control over the overall activities undertaken by the scientific community at international level ${ }^{101}$.

An unsigned document, which presents the attitude of the Ministry of Foreign Affairs management towards the Scientific Council, comes from the analyzed period. The document points out that the government intends to follow the views of scientists when carrying out reforms in the country. The Council, in which PAU representatives were present, made this possible. It consisted of persons invited by the Minister of Foreign Affairs. The authorities assigned a special role to the Academy, which should aim to 'coordinate with the foreign policy of the state the activities of those outstanding Polish scientific institutions whose work shines not only in the country, but also reaches beyond its borders ${ }^{\prime 102}$. Due to this role, the participation of the PAU in the Council was considered particularly desirable by the Ministry. The Ministry of Foreign Affairs also expected Poland to be closer to other countries on the level of their intellectual life, which was to facilitate the support of scientific institutions by the state. Another postulate was to use the scientific conventions as well as various contacts between scientists and institutions 'for the purpose of our propaganda abroad'. The Council acted as an intermediary in relations between the MFA and scholars. The ministerial authorities expected it to pass on its guidelines to scientists and institutions - above all the PAU. These postulates, however, contained some controversy, as the Ministry of Foreign Affairs expected to 'gather scientific evidence to support the M.F.A.'s policy thesis ${ }^{\prime 103}$.

\footnotetext{
99 AAN, MSZ, ref. no. 13430, sheet 48.

100 'rząd obecny pragnie opierać swe postępowanie na pogłębionej opinji sfer naukowych'.

${ }^{101}$ AAN, MSZ, ref. no. 13431, sheets 4-5.

102 ‘aby skoordynować z polityką zagraniczną państwową działalność tych wybitnych instytucyj naukowych polskich których twórczość promienieje nie tylko w kraju, ale sięga i poza jego granice'.

103 'zebrania naukowych dowodów popierających tezę polityki M. S. Z'. AAN, MSZ, ref. no. 13430 , sheets $34-35$.
} 
The importance attributed by the authorities to the Council was evidenced by the fact that on the occasion of its meeting, Franciszek Jan Pułaski presented an invitation to an audience with President Ignacy Mościcki to the President of PAU Rozwadowski and Secretary General Wróblewski ${ }^{104}$.

Between 8 and 10 June 1930, the Jan Kochanowski Scientific Congress was held in Krakow. The initiative for the congress came from the Society of Friends of Science in Lublin, but its realization was undertaken by the PAU. This means that the Academy was not only involved in international structures - such as the Council, the Union or the Commission - but also undertook organizational actions in which it wanted to interest the foreign scientific world. The convention was officially organized on the occasion of the 400th anniversary of Kochanowski's birthday. In the 'developing a synthetic approach to all the major areas of old Polish cultural life, and the results of the research of individual speakers should be presented at the Congress in an appropriate abridged and adapted manner, and then published in a separate publication'105. In the initiative of the congress, one can also find a desire to refer to the 16th century as the 'golden age' in Polish history. This served to build Poland's prestige on the international stage by showing its history and significant traditions. Invitations to participate in the congress were not addressed to domestic and foreign institutions, but individually - to individual historians of Slavic cultures and literature, as well as researchers interested in Old Polish culture. The then Secretary General of the PAU, Stanisław Kutrzeba, asked the Polish Ministry of Foreign Affairs and the Polish diplomatic missions to influence the foreign press and public opinion, in order to attract interest in the Jan Kochanowski Scientific Congress. Kutrzeba also hoped to obtain indications from the Ministry of Foreign Affairs and foreign missions regarding the invitation of relevant persons to participate in the convention ${ }^{106}$. Ultimately, the congress was attended by 1,005 people, representing various branches of science, education and culture ${ }^{107}$. The congress in Poland was attended by guests from England, Bulgaria, Czechoslovakia, Estonia, Finland,

${ }^{104}$ Ibidem, sheet 45.

105 'Pamiętnik Zjazdu Naukowego im. Jana Kochanowskiego' [‘Diary of the Jan Kochanowski Scientific Congress'], the aim of the event was defined as 'opracowanie syntetycznego ujęcia wszystkich ważniejszych dziedzin staropolskiego życia kulturalnego, przyczem wyniki badań poszczególnych referentów powinnyby zostać przedstawione na Zjeździe w odpowiedniem skróceniu i przystosowaniu, a następnie wydane w osobnej publikacji'. Pamiętnik Zjazdu Naukowego im. Jana Kochanowskiego w Krakowie 8 i 9 czerwca 1930, Kraków 1931, p. 3.

${ }^{106}$ J. Piskurewicz, Prima, pp. 110-111.

107 Pamiętnik Zjazdu Naukowego, pp. 10-11. 
France, Yugoslavia, Germany, Norway, Sweden, Hungary, Italy and the USA $^{108}$.

The activities of the Academy in building the prestige of the Republic of Poland in the international arena were recognized by the Polish Ministry of Foreign Affairs. This ministry tried to ensure that the PAU's work corresponded with the Polish national interest. The cooperation between the PAU and the Ministry of Foreign Affairs even made the Academy one of the elements of Polish foreign policy ${ }^{109}$. The Academy strove for the prestige of the state, because it enjoyed the authority in the international community of scientists who could influence the public opinion of Western societies - in order to gain greater favor for the reborn Republic. Taking this into account, in 1920, the Polish Loan Propaganda Committee in America asked the Academy to make an appeal to the American Polish community. The aim was to gain support for the Polish loan in America ${ }^{110}$. Two years later, the Upper Silesian Supreme People's Council asked the PAU to make an appeal to the chairman of the Upper Silesian Mixed Commission, Felix Calonder. The intention of this initiative was to convince Calonder of the need to defend the rights of the Polish language in the part of the Upper Silesian region left to the Germans. The importance of the PAU in the first years of the reborn Republic of Poland enabled it to undertake efforts aimed at the recovery of Polish cultural assets from Russia and Austria ${ }^{111}$. The Ministry of Foreign Affairs treated the Academy as the only institution which was entitled to represent Polish science on the international arena. This was reflected in many initiatives undertaken by the Ministry of Foreign Affairs together with the PAU to build the prestige of the reborn Republic in the international community ${ }^{112}$. The Polish authorities accepted and, as far as possible, supported the activities of the Academy in building the prestige of Poland. The Academy could not count on this before World War I - there was a lack of Polish statehood. The Austrian partitioner did not provide support on a wider scale, preventing the Academy from

${ }^{108}$ D. Rederowa, op. cit., pp. 96-97; J. Piskurewicz, Prima, p. 111.

109 J. Piskurewicz, Prima, p. 128.

110 'Głos Lubelski' 1920, 169, p. 1.

111 Józef Rymer, President of the Supreme People's Council in Upper Silesia, believed that 'interwencja Akademii Umiejętności jako najwyższej kulturalnej i naukowej instytucji w Polsce wywrze zbawienny wpływ na tok rokowań i przyczyni się do obronienia naszych słusznych praw' ['the intervention of the Academy of Arts and Sciences as the highest cultural and scientific institution in Poland will have a salutary impact on the course of negotiations and contribute to the defence of our legitimate rights']. After: J. Piskurewicz, Prima, p. 34.

112 See more: Ibidem, pp. 128-132. 
acting as a representative of the scientific interests of a non-existent state $^{113}$.

In the early 1930s, Stanisław Kutrzeba said: 'The Academy has achieved a very prominent position in Polish scientific life - perhaps more significant than academies in any other country, although those were sometimes incomparably richer in material resources, on which the capacity for scientific research and publishing depends so much ${ }^{\prime 14}$. This authority made the Academy - in scientific and cultural matters an important partner in the activities of the Ministry of Foreign Affairs, contributing to the growth of Poland's importance in the international arena. The PAU's prestige was built mainly through scientific stations, publications targeted to foreign audiences, contacts and initiated cooperation with the international scientific community. It also did so by means of scholarships and allowances for foreign research and studies and by allowing foreign members to join the PAU. Building its prestige, the Academy also undertook other initiatives - such as the Jan Kochanowski Scientific Congress. The importance of the PAU in building the prestige of the Second Republic of Poland was particularly evident in the Conseil International de Recherches and the Union Académique Internationale de Recherches et de Publications. These international scientific organizations provided a platform for scientific cooperation and development - initiated by national academies and influenced by the PAU ${ }^{115}$. In this perspective, the PAU initiatives reflected the specificity of national academies' forms of activity in building the prestige of new countries.

(translated by LINGUA LAB)

${ }^{113}$ As a consequence of the position of the Austrian authorities, the Academy Science Station in Rome was not allowed to be established earlier. D. Rederowa, op. cit., p. 127.

114 'W życiu naukowym Polski Akademia zajęła bardzo wybitne stanowisko - może znaczniejsze niż akademie w jakimkolwiek innym kraju, choć tamte były nieraz bez porównania bogatsze w środki materialne, od których w tak dużej mierze zależy możność badań naukowych i wydawnictw'. S. Kutrzeba, Polska Akademia Umiejętności 1872-1938, in: P. Hübner, op. cit., p. 164.

115 At the public meeting of the Academy - 13 June 1925 - the Vice President of the PAU, Jan Michał Rozwadowski, acknowledged: 'Możemy stwierdzić, że Polska Akademja Umiejętności, nie przestając być polską staje się coraz więcej naprawdę Akademją nauk europejską. Nie zaniedbując swego najbliższego obowiązku, jakim jest badanie i uprawianie rzeczy i spraw polskich, nasza Akademja wkracza coraz śmielej na szeroką arenę światową' ['We can say that the Polish Academy of Arts and Sciences, without ceasing to be Polish, is becoming more and more a truly European Academy of Sciences. Without neglecting its closest duty, which is to research and practice Polish things and affairs, our Academy is entering more and more boldly into the broad global arena']. Przemówienie, pp. $48-49$. 


\section{REFERENCES}

\section{Archival sources}

Archiwum Akt Nowych:

Ministerstwo Spraw Zagranicznych, ref. no. 13430, 13431, 13436.

Poselstwo RP w Wiedniu, ref. no. 349.

Archiwum Nauki PAN i PAU w Krakowie:

Polska Akademia Umiejętności, ref. no. I-157a.

Polska Akademia Umiejętności, Korespondencja Sekretarza Generalnego, ref. no. 75/21, $438 / 20,496 / 21$.

\section{Printed sources}

Konopczyński W., Dziennik 1918-1921, part 1, eds. P. Biliński, P. Plichta, Warszawa-Kraków 2016.

Kronika, 'Nauka Polska' 1927, 6.

Kronika zagraniczna, 'Nauka Polska' 1923, 4.

Natanson W., Sprawozdanie tymczasowe z przebiegu zgromadzenia konstytucyjnego 'Rady Międzynarodowej Badań Naukowych' odbytego w Brukseli, w dniach od 18. do 28. lipca 1919 roku, Kraków 1919.

Przemówienie wiceprezesa Jana M. Rozwadowskiego, 'Rocznik Polskiej Akademji Umiejętności' 1924/1925.

Skład Polskiej Akademji Umiejętności, 'Rocznik Polskiej Akademji Umiejętności' 1923/1924.

Sprawozdanie Sekretarza Generalnego Polskiej Akademji Umiejętności za czas od czerwca 1926 do czerwca 1927 r., 'Rocznik Polskiej Akademji Umiejętności' 1926/1927.

Sprawozdanie Sekretarza Generalnego Prof. K. Kostaneckiego, ‘Rocznik Polskiej Akademji Umiejętności' 1918/1919.

Sprawozdanie Sekretarza Generalnego z czynności Polskiej Akademji Umiejętności za czas od czerwca 1923 do czerwca 1924, 'Rocznik Polskiej Akademji Umiejętności' 1923/1924.

Sprawozdanie Sekretarza Generalnego z czynności Polskiej Akademji Umiejętności za czas od czerwca 1925 do czerwca 1926, 'Rocznik Polskiej Akademji Umiejętności' 1925/1926.

Sprawozdanie z wydawnictw i czynności Polskiej Akademji Umiejętności od czerwca 1924 do czerwca 1925, ‘Rocznik Polskiej Akademji Umiejętności' 1924/1925.

Statut Akademii Umiejętności w Krakowie, Kraków 1872.

Statut Polskiej Akademji Umiejętności, Kraków 1920.

Statut Polskiej Akademji Umiejętności, Kraków 1927.

\section{Periodical}

‘Głos Lubelski' 1920, 169.

\section{Studies}

Brzeziński A.M., Organizacja i formy międzynarodowej wspótpracy intelektualnej w ramach Ligi Narodów (1922-1939), 'Przegląd Zachodni' 2015, 3.

Brzeziński A.M., Polska Komisja Międzynarodowej Wspótpracy Intelektualnej (1924-1939), Łódź 2001.

Gdańsk. Przeszłość i teraźniejszość, ed. S. Kutrzeba, Lwów-Warszawa-Kraków 1928.

H.D., Stosunki naukowe Polski z zagranica, 'Nauka Polska' 1925, 5.

Handelsman M., Uniwersytet Warszawski. Z racji pierwszej rocznicy wskrzeszenia Wszechnicy Warszawskiej, 'Świat' 1916, 47.

Historja Ślaska: od najdawniejszych czasów do roku 1400, vol. 1, ed. S. Kutrzeba, Kraków 1933. Hübner P., Od Towarzystwa Naukowego Krakowskiego do Polskiej Akademii Umiejętności, in: 
Studia i materiały do dziejów Polskiej Akademii Umiejętności, vol. 1, Kraków 2002.

Konopczyński W., Nauka polska na terenie międzynarodowym, 'Nauka Polska' 1920, 3.

Kutrzeba S., Nauka a państwo, 'Nauka Polska' 1920, 3.

Kutrzeba S., Polska Akademia Umiejętności 1872-1938, in: P. Hübner, Od Towarzystwa Naukowego Krakowskiego do Polskiej Akademii Umiejętności, in: Studia i materiały do dziejów Polskiej Akademii Umiejętności, vol. 1, Kraków 2002.

Lichocka H., Akademia Umiejętności (1872-1918) i jej czescy członkowie, ‘Prace Komisji Historii Nauki PAU' 2015, 14.

Muszkowski J., Międzynarodowa wspótpraca intelektualna wczoraj i dziś, ‘Życie Nauki. Miesięcznik Naukoznawczy' 1947, 3, 13-14.

Pamiętnik Zjazdu Naukowego im. Jana Kochanowskiego w Krakowie 8 i 9 czerwca 1930, Kraków 1931.

Piskurewicz J., Prima inter pares. Polska Akademia Umiejętności w latach II Rzeczypospolitej, Kraków 1998.

Piskurewicz J., W służbie nauki i oświaty. Stanisław Michalski (1865-1949), Warszawa 1993.

Rafalska-Łasocha A., Maria Skłodowska-Curie i jej kontakty ze środowiskiem krakowskim, Kraków 2015.

Rederowa D., Formy wspótpracy Polskiej Akademii Umiejętności z zagranica (1873-1952), 'Studia i Materiały z Dziejów Nauki Polskiej' 1966, 10.

Róziewicz J., Róziewicz H., Z dziejów międzynarodowych kontaktów naukowych Polski w latach 1919-1939, 'Problemy Polonii Zagranicznej' 1975, 9.

Siedlecki M., Nauka polska na terenie międzynarodowym, ‘Nauka Polska' 1920, 3.

Stachowska K., Z działalności wydawniczej Polskiej Akademii Umiejętności - starania o upowszechnienie za granica polskiej myśli naukowej w latach 1873-1952, 'Rocznik Biblioteki PAN w Krakowie' 1973, 19.

Majer J., Wstęp. Sprawa przeobrażenia Towarzystwa Naukowego krakowskiego na Akademije Umiejętności, in: Pamiętnik piętnastoletniej działalności Akademii Umiejętności w Krakowie 1873-1888, Kraków 1889.

\section{STRESZCZENIE}

W artykule ukazano znaczenie Polskiej Akademii Umiejętności w budowaniu prestiżu odrodzonego w 1918 roku państwa polskiego. Artykuł dotyczy w głównej mierze pierwszych lat niepodległości, w których Akademia podjęła się działań, mających na celu zyskanie nauce polskiej międzynarodowej renomy. Operacjonalizując problem analizowano zakres i charakter współpracy PAU z władzami RP - w szczególności z Ministerstwem Spraw Zagranicznych. Artykuł powstał w oparciu o materiały źródłowe zarówno archiwalne, jak publikowane - oraz literaturę przedmiotu. Informacje zawarte w źródłach i opublikowanych pracach poddano krytycznej ocenie - uwzględniającej specyfikę analizowanego materiału. W oparciu o statutowe cele PAU, przedstawiono różne formy prac Akademii, z jakimi wiązano budowę znaczenia nauki polskiej poza granicami kraju. Odwołano się do zaangażowania PAU w prace międzynarodowych organizacji naukowych - Conseil International de Recherches oraz Union Académique Internationale de Recherches et de Publications. Wpływ polskiej kultury narodowej (wspieranej i rozwijanej przez PAU) na prestiż II RP na arenie międzynarodowej, wskazywał, że działania PAU były konieczne wobec pragnienia ugruntowania pozycji Rzeczypospolitej $\mathrm{w}$ środowisku uczonych z innych państw - po latach niedoceniania, marginalizowania i przypisywania innym polskiego dorobku naukowego i kulturalnego. Ustalono znaczenie wsparcia działań PAU przez MSZ, korzystne efekty, ale i zagrożenia związane z wejściem polityki na grunt nauki. 
Słowa kluczowe: Polska Akademia Umiejętności, nauka, kultura narodowa, II Rzeczpospolita, Ministerstwo Spraw Zagranicznych, prestiż

\section{ABOUT THE AUTHOR}

Mateusz Hübner - currently a PhD student (4th year) at the Faculty of History of the Nicolaus Copernicus University. He was born in 1993. In 2017, he defended his Master's thesis on the Piłsudski community. As part of the eleventh edition of the Władysław Pobóg-Malinowski Competition for the Best Historical Debut of the Year in the field of recent history, he received the 1st degree award from the Institute of National Remembrance and the Institute of History of the Polish Academy of Sciences for this work. He has taken part in several foreign scientific trips. In 2018, he was awarded the Jan and Suzanne Brzękowski scholarship - in order to conduct research in the Polish Library in Paris for a doctoral thesis on the National Culture Fund. For realizing the same goal in London, he received a scholarship from the De Brzezie Lanckoroński Foundation for 2019. He has co-organized several conferences and debates. He takes part in the editorial work of publications on the history of the Second Republic of Poland. He is the author of several professional articles and reviews. As a representative of doctoral students, he was elected to the Council for Scientific Discipline of History at the Faculty of Historical Sciences of the Nicolaus Copernicus University (2019-2023 term). From December 2020, an assistant at the Institute of the History of Science of the Polish Academy of Sciences. 